\title{
The Badge
}

\author{
Lisa Robertson
}

\section{L'écusson}

Vivienne Westwood, designer de la culture punkau début du mouvement et par la suite pour le monde de la haute couture, source de créations extravagantes qui ont remporté des succès inattendus (souliers à bouts carrés munis de trois langues ou bottes lacées "hip-hop») est le sujet de cet hommage. Dans la première partie du texte, le pillage poétique du passé que fait Westwood est la source d'inspiration de deux sonnets: «Big plum coloured syllables creak / like leather / across the sixteen centuries mud». Ces chansons freaks en l'honneur d'une "dignité précoce» sont suivies d'un «portrait» à la manière de Westwood qui exprime une vision de la vie comme dans une peinture où le non conformisme est traitécomme une qualité, une texture, une couleur: "Je fabrique une braguette à partir d'une pièce de tissu et j'y pratique une ouverture... Les pirates y seraient entrés et je les y aurais attendus. Il y avait un élément de charme.». La barbarie humaine est concrétisée de la même manière dans cette "peinture» par un écusson en fourrure de léopard, une figure métonymique de conquête impérialiste.

"Giantesses will stop the world when they want to."

-Vivienne Westwood

My lithe dress wilts or fetters

Whistle a bit so I know how to find you

That sunburst's your mink lined choker

A sort of weather

Peeled as low

Yellow as fleet

Cruised when fallow

And very happy

The world is not you

But I believe it is 
Big plum coloured syllables creak Like leather Across the sixteen centuries mud Just let me be judged from your lurid couch

In my dream of Justice

Precocious dignity is just a song

Gone wild deep bordeaux

Seven sided

A gauntlet

Where are your square-toed triple-tongued

Grey leather lace-up hip-hop shoes

From 1984?

Yet I'd be limiting my examples if

Desire so deep

Were simply modern

You are nothing like us

Your ornaments

Are gilded flukes 


\title{
Portrait of Vivienne Westwood
}

\author{
The little story of the Queen.
}

I didn't want to live in this painting; I was born to work with fact. Opinions should be formed on the basis of fact.

I started with the need to stimulate my Hellenist. The Romantic theme was the world, and plunder of the gaudy world. I wanted to earn my living. I started from an intellectual point. The techniques came out on the collar. You couldn't develop them anywhere else. I thought I'd do a catwalk. It'd be romantic. I made a codpiece from a piece of fabric and cut across it. She would be irate, but I understood cloth. The pirates would get into it and hang there waiting. There was an element of charm. They thought it formed the medium for a polemic, yet it was all part of sex: The sparkling loves Madame Vionnet took were all paintings really.

\section{You've got Titian velvet}

This black PVC

This lovely leopard fur

The badge of our barbarity

It is not less civilized. They may be intellectually poignant, but do not believe that $\sin$ is anything but elegance. I am pushing the idea of sexual elegance. I will promote the ideas of my strange Pagan.

I have worked with factories and I wanted it to look accidental - as if it really were country life. If you took this precise red it would remind you of fox-hunting. Each colour brings this charge of content. I will make all of the outfits as if people wanted to patronize art. Madame Vionnet knew that perverse equality. You have to fabricate these restraints. It is not possible to have the unorthodox, but I work as if it really were a quality. Each texture sparks this charge of want. To use intelligence without a feeling is just to play around with the world.

I do things in a little adventure named Vivienne Westwood. 